\title{
Prekmurski členki v Pleteršnikovem slovarju
}

\author{
MARUŠKA AGREŽ \\ Univerza v Ljubljani, Filozofska fakulteta, Aškerčeva c. 2, \\ SI-1000Ljubljana, agrez.maruska@gmail.com
}

\begin{abstract}
Prispevek obravnava prekmurske členke v Pleteršnikovem slovarju in ostalih relevantnih popisih besedja ter $\mathrm{v}$ izbranih besedilih prekmurskega knjižnega jezika. Tipično prekmurski je le ešče. Nekateri členki so značilni za celoten vzhodnoslovenski prostor. Drugi se pojavijo tudi v kajkavščini. Od osrednjeslovenskih in sodobnih slovenskih knjižnih členkov se prekmurski členki razlikujejo leksikalno, glasoslovno in besedotvorno. Etimološko so blizu praslovanskim variantam.
\end{abstract}

This paper discusses Prekmurian particles in Pleteršnik's dictionary and other relevant word inventories and selected texts written in the Prekmurian standard language. The particle, typical of the Prekmurian language is ešče. Some particles are specific to Eastern Slovene while others also occur in Kajkavian. Prekmurian particles differ from Central and Standard Slovene particles in a lexical, phonological, and derivational sense. Many Prekmurian particles are etimologically similar to their Proto-Slavic variants.

Ključne besede: Pleteršnikov slovar, členki, prekmurščina, prekmurski knjižni jezik, vzhodnoslovenski jezik, kajkavščina

Key words: Pleteršnik's dictionary, particles, the Prekmurian language, the Prekmurian standard language, Eastern Slovene, the Kajkavian language

\section{Uvod}

\subsection{Teoretske osnove in izbira gradiva}

V prispevku bodo obravnavani prekmurski ${ }^{1}$ členki, tj. besede, ki pomensko modificirajo določen del besedila. Upoštevana bo funkcijska delitev na modalne, ki

\footnotetext{
${ }^{1}$ Kot prekmurski so v prispevku mišljeni členki, prisotni v prekmurščini, tj. prekmurskem knjižnem jeziku in narečjih.
} 
izražajo tvorčevo razmerje do povedanega in se običajno navezujejo na stavek; poudarne, ki izpostavljajo običajno stavčnočlensko izražen del besedila kot pomembno informacijo; povezovalne, ki pomensko povezujejo določen del z ostalim kontekstom, ${ }^{2}$ in časovne, ki prinašajo oz. poudarjajo informacijo o času (prim. Černelič 1993: 224-225, Agrež 2014c).

Osrednjeslovenski ${ }^{3}$ členki so zelo podobni knjižnim ${ }^{4}$ v smislu nabora in rabe (prim. Korošec 2009, Agrež 2013, 2014a). Prekmurščina je imela zaradi zgodovinsko-geografskih okoliščin manjši vpliv na razvoj sodobne slovenske knjižne norme (Jesenšek 1992, 2013: 31-40). Zato je pri prekmurskih členkih pričakovati več razlik s sodobnim slovenskim knjižnim jezikom.

\subsection{Metode dela}

Izhodišče za obravnavo prekmurskih členkov bo Pleteršnikov Slovensko-nemški slovar kot »najstarejši resnejši prikaz prekmurščine« (Narat 1998: 179). Med izrazi s kvalifikatorjem ogr., označenimi večinoma kot vezniki, prislovi ali medmeti, bodo izpisani tisti, ki ustrezajo zgornji opredelitvi členkov. Natančneje bodo obravnavana gesla $\mathrm{v}$ drugem delu slovarja $(\mathrm{J}-\check{Z})$, dodana pa jim bodo pomensko sorodna gesla iz prvega dela (A-I). Pomensko bodo obravnavani členki izražali čas, sklep, dodajanje s poudarjanjem, minimalnost, pritrdilnost, izvzem in vprašanje. Navedeni bodo v naslovih, kjer jim bo pripisan vir nahajanja. Največ jih je iz Cafovega slovarskega gradiva, ki ga Pleteršnik (2006: VI) označi kot pomemben vir prekmurskega besedja, četudi zaradi napak pri prepisovanju to izčrpno gradivo ni vedno zanesljivo (prim. Narat 2005, Jesenšek 2007). Navajam seznam oznak virov, za potrebe prispevka prirejenih po Pleteršniku (2006: XIV-XVII): C. = Cafovo slovarsko gradivo; M. = Miklošičeva dela; Let. $=$ Letopis Matice slovenske (od 1869); Valj. = Valjavčeva dela; Vest. = Vestnik, znanstvena priloga Zore (1873-75).

Pri obravnavi bo upoštevan še Slovar stare knjižne prekmurščine (Novak 2006) in ostali relevantni normativni priročniki oz. jezikovne analize (Bezlaj 1976-2005, Novak 1985, Rajnar 1998, Ivanšek 2009, Pavel 2013). Ker ima prekmurščina kot jezik vzhodnoslovenskega prostora skupno panonsko narečno bazo z vzhodnoštajerskim knjižnim jezikom in narečji (Jesenšek 1992: 175), bo pozornost usmerjena tudi na stanje $\mathrm{v}$ vzhodnoštajerskem prostoru, pri čemer bodo v pomoč relevantne jezikovne analize in slovarji (Unuk 1995, Koletnik 1995, 2001, Rajh 1998, 2010). Zaradi večstoletnih stikov prekmurščine s kajkavščino 5 (Jesenšek 1992: 177-180) bo s pomočjo ustreznih slovarjev (Katičić 1984-2005, Hrg 1996, Večenaj, Lončarić 1997) upoštevano tudi stanje v kajkavščini.

\footnotetext{
${ }^{2}$ Kontekst zajema sobesedilo in zunajbesedilno dejanskost.

${ }^{3}$ Izraz osrednjeslovenski zajema osrednjeslovenski knjižni jezik in narečja.

${ }^{4}$ Izraz knjižni se nanaša na sodobni slovenski knjižni jezik.

${ }^{5}$ Gre za kajkavski knjižni jezik in narečja.
} 
Raba obravnavanih členkov bo analizirana v prekmurskih knjižnih besedilih med 18. in 20. stoletjem: KŠ = Š. Küzmič (1771); Koš = Košič (1833); KM = M. Küzmič (1851); ${ }^{6} \mathrm{Kl}=$ Klekl (1904).

Pri izpisu slovarskih gesel, reprezentativnih zgledov iz besedil in možnih izraznih variant členkov, izpisanih v oklepajih pred številom pojavitev za posamezno besedilo, bodo zanemarjena edino diakritična znamenja. V metajeziku bodo šumevci in sičniki prečrkovani skladno s sodobnim slovenskim črkopisom. V izogib navajanju istih zgledov na več mestih, bodo v nekaterih zgledih podčrtani tudi členki, obravnavani v drugih razdelkih, kjer bo navedena številka ustreznega ponazoritvenega zgleda.

\section{Analiza gradiva}

\section{1 Čas}

\subsubsection{Ešče (C.), išče (C.), jošče (C., M.)}

Išče je tvorjen iz vseslovanskega členka $i$ - in šče (Bajec 1954: 197). Jošče je nastal po praslovanski osnovi $o$ - (*ǒ̌če) (Bezlaj 2005: 27). V današnjem prekmurskem narečju in besedilih prekmurskega knjižnega jezika ju ni zaslediti. ${ }^{7}$ Jošče je naveden na Dalmatinovem registru (Ahačič idr. 2011: 165) in prisoten v pesmaricah. ${ }^{8}$ Išče v asimilirani varianti iše Pleteršnik navaja tudi za dolenjski prostor 16. in 17. stoletja in za belokranjsko narečje. Pojavi se tudi pri slovenskih protestantih, predvsem pri Krelju (Bajec 1954: 197, Ahačič idr. 2011: 149). Oba izraza sta prisotna tudi v kajkavščini. Zato je možno, da so ju prekmurski avtorji občutili kot kajkavska in se jima posledično izogibali (prim. Jesenšek 1992: 177-178). ${ }^{9}$

V prekmurskem knjižnem jeziku je bil v rabi ešče (prim. Novak 2006, Markoja 2004: 155), ki je nastal po praslovanski osnovi e- (*ešče) (Bezlaj 2005: 27). Prisoten je tudi v obravnavanih besedilih (escse: Ko 4; K1 12) in v narečjih. Razlik v rabi s knjižnim še ni opaziti ${ }^{10}$ (prim. Markoja 2004: 155).

Časovni ešče običajno stoji znotraj stavka in izraža nedopolnjenost dejanja oz. stanja, $(1,2)$. Ešče se pojavi tudi kot poudarno-povezovalni členek, $(3,4)$. Stoji pred skopusom, ${ }^{11}$ ki ga izpostavlja kot pomembno informacijo ter dodaja ostalim sorodnim informacijam v kontekstu (prim. Pavel 2013: 265).

\footnotetext{
${ }^{6}$ Gre za ponatis Küzmičevega Szlovenszkega szilabikarja (1780).

${ }^{7}$ Za podatek se zahvaljujem prof. dr. M. Jesenšku.

${ }^{8}$ Za podatek se zahvaljujem prof. dr. I. Orel.

${ }^{9}$ Razlaga velja za vse obravnavane členke, pri katerih je opozorjeno na prisotnost v kajkavščini in redkost $v$ prekmurščini.

${ }^{10}$ Če ni posebej opozorjeno, velja tudi za ostale fonetične oz. besedotvorne variante knjižnih.

${ }^{11}$ Izraz skopus je rabljen po nemških jezikoslovcih (npr. Altmann 1976) in označuje del besedila, na katerega se določeno jezikovno sredstvo nanaša.
} 
(1) /S/zpoznavsi, ka sze je escse na ete szvejt nej naroudo, ki bi vszem lidem vsze mogao vgoditil./212 (Košič 1833: V)

(2) IS/zamo szluga v pamet vzeme, ka je z poti dolizablodo. "Devet let klacsim zse to ceszto - veli on - ali to sze escse z menom nigdar nej zgodilo.« (Klekl 1904: 14)

(3) IS/zo sztarinszki Vogri escse nistere drüge narode med szebe notri prijali/./ (Košič 1833: X)

(4) »Mati - pita nemirovno - pa bi escse priso k nam Jezus? « »Kaj pa nebi - trosta ga ona - pride, ali da je dnesz tak velki szneg, komaj de mogo priti k nam z vesznice, ali vütro, ja te zagvüsno pride." To odlasanje szinovi nej bilo szploh po voli-escse eden celi den de mogao csakati. Ali dönok sze je vtisao. (Klekl 1904: 12)

\subsubsection{Vre (C.)}

Nastal je po rotacizmu (Bajec 1954: 225, Bezlaj 1976: 154). Že Pleteršnik ga navaja tudi za Ribnico, Belo krajino ter za Istro in Goriško. Pojavi se tudi v kajkavščini, a zaradi rotacizma ne more biti hrvaški.

V prekmurščini je evidentiran le pri Bakošu (Novak 2006: 848). Sicer je pogostejši knjižni že (zse: Koš 1 ; Kl 12). Časovni že običajno stoji znotraj stavka in poudarja dopolnjenost ali trajanje dejanja, $(5,6)$. Časovno-poudarni že navadno stoji pred dotičnim prislovnim določilom časa. Poudarja dolgo trajanje stanja, $(7,8)$.

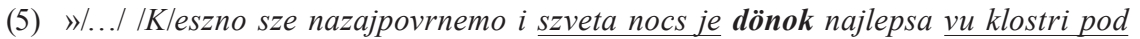
jalicsom i pred jaszlicami.« »Ali da je pa od toga dönok lepse ono veszelje, stero vidimo na lici obdarüvani sziromakov i male decsice, ki szo zse zmestno csakali Jezuseka." (Klekl 1904: 13)

(6) Kda je mati zaszpala, zse je znao, ka de csiniol./ (Klekl 1904: 12)

(7) Domovino szi pomiszli kakti tvojo mater, stera 'se davno 'selej, ka bi vszi 'snje Jesikom 'siveli/./ (Košič 1833: XI)

(8) Zse devet let vlacsim te szani z vszefele blagom! i csi sze nam glih veszelijo lüdje, dönok tak gledajo, ka njim je nikaj nej zadoszta, pa szani vlacsiti po sznegi je tüdi nej spaiz. (Klek1 1904: 14)

\subsubsection{Veče (C.)}

Gre za starejšo varianto knjižnega več, izvorno praslovanskega primernika *vęte (Bezlaj 2005: 28). Evidentirana kajkavska narečna varianta je večve ‘že’. Pleteršnik veče 'že' navede le za goriško področje, prekmurski veče pa ima naveden samo enak pomen kot knjižni več. Torej izraža oz. poudarja konec dejanja ali stanja. V besedilih se pojavi le varianta več (vecs: K ̌̌ 1).

(9) Vi fzte fzou zemle: csi fze pa fzou fzkvari, fzkim fze bode fzolila? Nikaj ne vala vecs: nego da fze vo vr'ze, i fklacsi od lüdi. (Küzmič 1999: 14)

\footnotetext{
${ }^{12}$ Vse podčrtave in polkrepki tisk v zgledih so delo avtorice prispevka.
} 


\subsubsection{Zavzpet (C.) in pali (Let.)}

Zavzpet je etimološka varianta vzpet (psl. *vzpȩt) z dodano predpono za-. Pomen 'spet' je prvotni pomen besede pa (*pakb) (Bezlaj 1995: 1). Varianta pali je tvorjena iz pa in poudarjalne členice li (Bajec 1954: 197). Tako pali kot časovni pa (pa: KS 2 ; pali: KŠ 1) sta prisotna v celotnem vzhodnoslovenskem prostoru.

V primeru (10) bi bilo pa smiselno razložiti tudi kot dodajalni členek, a primerjava z ostalimi prevodi Biblije (Trubar, Dalmatin, Japelj, Chráska, SSP in SSP3), ki imajo na istem mestu spet oz. zopet govori v prid izražanju ponavljanja vzorca dogodkov - Satanovega skušanja Jezusa, (10), in s pali nasprotij med tem, kar so Jezusovi učenci slišali od drugih, in kaj jim je o istem problemu povedal Jezus, (11).

(10) Teda ga je vzeo vrag vu fzveto mefzto, i pofztavo ga je na perotnicso czerkvi. I erkao je nyemi: csi fzi Szin Bo'zi; vrzi fze doli. Ar je pifzano: kaj Angyelom fzvojim zapovej od tebe; i na roke te vzemejo, da kak ne vdariš vu kamen noge tvoje. Erkao je nyemi Je'zus: pa je pifzano; ne Jkusavaj Gofzpodna Boga tvojega. Pa ga vzeo vrag na edno jako vifzoko gorou, i poka'ze nyemi vfza kralefztva toga fvejta i nyih diko. I veli njemi: eta vfza tebi dam, csi doli fzpadnovfi me molo bodes. (Küzmič 1999: 11)

(11) Povejdano je pa: kaj, fterikoli odpifzeti 'zeno fzvojo, naj ji da raclocsnya lizt. Jafz pa velim vam: kaj, fterikoli odpifzti 'zeno fzvojo brezi zrokapraznofzti, vcsini jo praznuvati; i fterikoli odpufcseno vzeme praznuje. Pali fzte csuli, kaj je povejdano tim fztarifim: krivo ne prifzegaj, daj pa Gofzpodni prifzego tvojo. (Küzmič 1999: 16)

\subsection{Sklep}

Teda (C.)

Teda (psl. *tъda), starejša etimološka varianta tedaj, je v prekmurskem knjižnem jeziku (Novak 2006: 753-754) pomensko razložen samo kot 'tedaj', v slovarskih zgledih pa ni dovolj sobesedila, da bi se lahko ugotovilo, ali gre za prislovno, vezniško ali členkovno rabo. ${ }^{13}$ Členek tedaj izraža sklep na prej povedano, a delov besedila ne povezuje v priredno strukturo.


7). Vzhodnoslovenski te že Pleteršnik navaja kot vzhodnoštajersko varianto tedaj (prim. Agrež 2014b). Tak, ki ga Pleteršnik navaja brez informacij o viru oz. kraju nahajanja, je pogost v vzhodnoslovenskem prostoru in je reducirana varianta knjižnega tako.

${ }^{13}$ Tudi pri v nadaljevanju predstavljenih besedah te in $t a k$ je funkcije iz zgledov v obravnavani strokovni literaturi večkrat težko določiti. Iz obravnavanega gradiva bo v oklepajih izpisano celotno število pojavitev, natančneje obravnavana pa bo pri vseh treh izrazih le členkovna funkcija. 
Te in tak navadno stojita znotraj stavka, $(13,14,15,17)$ in redkeje na prvem mestu, $(12,14,18)$. Tak je rabljen tudi kot pritrdilnica, (16). Gre za nadnarečno rabo (tako in tako tako). $\mathrm{V}$ podanem primeru podvojena zveza členkov tak 'da' in nej 'ne' stavčnočlensko nastopa v vlogi povedkovega določila, saj gre za zapis poročanega govora. Tak se nadnarečno (tako, tako in tako) pojavi tudi kot modalni členek za poudarjanje znanega oz. samoumevnega dejstva, $(17,18)$.

(12) »Jeli pride doktor Jezusek?« szpitava decsak. »Ja pride, csi bodes domo so.« »Te mo rad so, oh te mi mati ne vmerjejo." (Klekl 1904: 15)

(13) Csi pa travo polfzko, ftera dnefz jefzte, a vütro fze pa vpecs vr'ze, Boug tak oblacsa, nejli vafz zvnougim bole, malovorczi. Ne fzkrbte tak govorecsi: ka bomo jeli? I ka bomo pili? (Küzmič 1999: 20)

(14) A: Boug je povfzed nazoucsi. / B: Jeli je tak pri nafz tüdi? / A: Tüdi je nazoucsi. / B: Tak vidi, csüje, i zna vfza dobro? / A: Vfza vidi, csüje $i$ zna dobro. (Küzmič 1851: 29)

(15) /P/remiszlivsi, kai te szpokani zvon vküpszpravla raztepene lüdi vu bo'so hi'so. dobrovolni bodo zagovarjali moje falinge. Nemouti sze tak nikaj moj lübleni mali Zemlak! Nego eto pouleg navadnoga guczanya veksega tala Szlovenov piszano Gramatiko dobrovolno primil// (Košič 1833: VI)

(16) Bojdi pa rejcs vafa: tak tak, nej, nej; kaj je pa vifse toga, zhüdnoga je. (Küzmič 1999: 16)

(17) Szloven szlovenszki tak neposabi, ali dönok za tebe: 1) Je dosztojno i du'snoszt po Vogrszkom znati. (Košič 1833: XII)

(18) 》So mo jasz i zazovem tebi doktora." pravi on. "Oh szinek moj, vu tom bozsnom vremeni kak bi mogao ti to vcsiniti. Sztopi bole k meni, tak szi ti escse trost moj jedini.« (Klek1 1904: 12)

\subsection{Dodajanje in poudarjanje}

\subsubsection{Tolikajše (C.), $i$}

Tolikajše je naveden kot prekmurska tvorjenka iz praslovanskega pridevniškega zaimka *tolikb (Bezlaj 2005: 193-194). Evidentiran je pri Agustiču (Novak 2006: 762). V pregledanem gradivu ni prisoten. Pojavi se tudi v Središki prisegi iz prve polovice 18. stoletja, na katere jezik je vplivala kajkavščina. Možno je, da gre za hrvaško besedo.

V prekmurskem knjižnem jeziku je $i$ 'tudi', stara slovanska varianta besede in (Šolar 1959: 14), pogost v besedilih 18. stoletja. Kasneje ga začne nadomeščati tüdi, vzhodnoslovenska glasovna varianta knjižnega tudi (i: KŠ 10; Koš 4; KM 1; tüdi: KM 4; Koš 2; K1 8) (prim. Markoja 2004: 154).

Bistvenih razlik v rabi s knjižnim tudi ni. Temeljni prvini obeh členkov sta dodajanje in poudarjanje (prim. Šolar 1958). Najpogosteje nastopata kot poudarno-povezovalna členka. I vedno stoji pred skopusom, $(19,20)$, tüdi pa pred skopusom, $(21,22)$, ali za njim, $(23,24)$ (prim. prav tam). V primeru (23) drugi 
tüdi sodeluje pri oblikovanju pritrdilnega odgovora tako, da uvaja ponovljeno sestavino propozicije vprašanja. Tüdi se lahko pojavi kot modalni členek v pomenu 'res' in stoji znotraj povedi, (25).

(19) Bla'zeni fzte, gda vafs pfzuvali i preganyali bodo, i gucsali bodo vfzo hudo rejcs prouti vam lazecsi. Radujte fze ino fze vefzelte: kaj je vas najem veliki vu nebefzaj. Ar fzo preganyali i proroke: ki fzo pred vami bili. (Küzmič 1999: 14)

(20) Da je Krifztus Boug, i Cslovik, morebiti i dvej naturi ma? (Küzmič 1851: 32)

(21) A: Kakda nafz je fztvouro Boug na fzvoj fz. Kejp, jeli na tejlo, ali pa na düso gledoucs? / B: Na düso gledoucs. / A: Zakaj pa tüdi nej na tejlo gledoucs? (Küzmič 1851: 30)

(22) IK/i lübi szvoje Kralevcsine, tiszti je tüdi zavezani naprejpomagati, razseriti nye navadnoga Jezika. (Košič 1833: VIII)

(23) A: Boug je poufzed nazoucsi. / B: Jeli je tak pri nafz tüdi? / A: Tüdi je nazoucsi. (Küzmič 1851: 29)

(24) »Mamica, jeli dnesz k nam tüdi pride mali Jezus?" /.../ »Pride, ja pride szin moj» odgovori mati, stera je betezsna lezsala na trdoj poszteli. (Klekl 1904: 11)

(25) »/T/ak sze mi vidi, da bi eti pod drevom nikaj lezsalo.« /.../ i ednoga pojba je z sznega vöpotegnola. I.../ »Na, devet lejt vlacsim zse te szani - muvi Tomas - i to sze escse nej sgodilo z menom. Pa je zse tüdi kmica." (Klekl 1904: 14-15)

Tüdi je lahko soroden pomenu 'niti', (8). V tem pomenu se pojavita še $n i$ (ni: KŠ 1) in nanč (nancs: Kl 2), (29, 30). Oba sta navedena v prekmurščini. V vzhodnoslovenskem prostoru je evidentirana še glasovna varianta najnč.

(26) Csi pa ne odpufztite lidem prefztoplenya nyihova; ni ocsa vas ne odpufzti vam prefztoplenya va/s. (Küzmič 1999: 19)

(27) Tomas je pot szekal z szanami, ali ednok je szamo pipo z lamp vövzeo govorecsi: "Prav lepo delo je, csi sto med sziromakami almostvo deli; ali jesztejo med njimi, ki szo niksega dara nej vredni." »Tomas - veli merno karajocsa Benedikta - pa nancs to malo veszelje nevoscite na te szvetke sziromakam?« (Klekl 1904: 13-14)

\subsubsection{Vprav (M., C.)}

Vprav je starejša knjižna varianta prav. Izvorno je »odreveneli pridevnik « (Bajec 1954: 220). Pleteršnik ga navaja še za Levstikove pripiske k Miklošičevemu slovarju in Navratilove spise. V besedilih se pojavi le knjižni prav kot poudarjalec visoke stopnje določene lastnosti, (27). Pomen je soroden prislovu zelo. Ker se je po njem težko vprašati in ga je zato težko določiti kot levi prilastek, je poudarni členek. Pojavi se tudi knjižna varianta ravno (ravno: Koš 1) v vlogi poudarnega členka za izpostavljanje natanko določene informacije, (28). $\mathrm{V}$ popisih prekmurskega besedja se pojavlja tudi nemčizem glih oz. njegova narečna varianta gli. 
(28) IS/zo sztarinszki Vogri escse nistere drüge narode med szebe notri prijeli: i ravno te je zrok, ka je vogrszki Jezik pote'seni i zavr'senil// (Košič 1833: X)

\subsection{Minimalnost in pritrdilnost}

A. Pavel (2013: 261) je pritrdilnice (in vprašalne členke) uvrstil med načinovne prislove, a se je zavedal, da »brez posebnega določanja načina samo potrdijo, zanikajo ali podvomijo v trditev ali pa jo naredijo vprašalno«.

\subsubsection{Bar (C.); končimar (C.)}

Končimar in bar izražata minimalnost. Torej imata podoben pomen kot knjižni vsaj. Bar je turcizem, prisoten v celotnem vzhodnoslovenskem prostoru in ostalih južnoslovanskih jezikih ter madžarščini (Pleteršnik 1894/95, Bezlaj 1976: 11). Bajec (1954: 205) tvorbi iz simpleksa *konb oz. *konъ in členka -či konče in konči označi kot značilnost t. i. vzhodnih narečij. Pleteršnik navede še varianto končema samo kot štajersko in konči kot štajersko in belokranjsko. Bar in konči s svojimi tvorjenkami vsebuje tudi kajkavščina. V beltinškem govoru je prisoten končibar (Novak 1985: 47).

Kot hapaks se pojavi končimar (koncsimar: Koš 1) v vlogi poudarno-modalnega členka, ki izpostavlja določeno ravnanje kot tvorčevo minimalno željo, (29).

(29) /P/ohaszni moje trüde, stere csi necses placsati, koncsimar za nyih volo me preosztro nepokastigaj. (Košič 1833: VI)

2.4.2 Ve (C.), venda (C.); za istino (Valj.)

Protivno-dopustni pritrdilnici venda in ve 'ja, saj' sta značilni za celoten vzhodnoslovenski prostor. Verjetno enako kot vendar izvirata iz psl. *viny 'vsekakor' in členice -že (Bezlaj 2005: 297). Pleteršnik venda 'verjetno' navede kot vzhodnoštajerski, v pomenu 'ja, doch' pa kot prekmurski. Ve navede samo v slednjem pomenu in za obe področji. V kasnejših popisih besedja sta za vzhodnoštajerski prostor izpričana oba pomena. V prekmurskem knjižnem jeziku pa besedi nista evidentirani. Kot kajkavsko F. Bezlaj (prav tam) navede vinda. V prekmurskih narečjih je naveden $v e j$, lahko kot $v s a j$ v smislu izražanja minimalnosti ali kot protivno-dopustni saj.

$\mathrm{V}$ vzhodnoslovenskem prostoru sta navedeni pritrdilnici istina in zaistino. Slednja se pojavi tudi v besedilih (zaijztino: KŠ 3; zaisztino: Koš 1). Etimološki izvor teh splošnoslovanskih izrazov ni čisto znan (prim. Bezlaj 1976: 213). Pri Küzmiču se zaistino pojavi kot del ustaljene biblijske fraze zaistino velim tebi (resnično povem ti), (30). Gre za metabesedilni stavek, ki povedano zagotavlja 
kot resnično in poudarja kot pomembno. Sicer se zaistino pojavi kot modalni členek, s katerim želi tvorec naslovnika prepričati v resničnost povedanega, (31).

Med pritrdilnicami se pojavijo tudi nemčizmi dönok, ja in zagvüšno (dönok: KS̆ 1; Ko 3; KM 2; Kl 6; dön’k: Ko 1; ja: K1 7; zagvüsno: K1 1). Pleteršnik jih zaradi puristične prečiščenosti besedja v slovarju ne navaja (prim. Orožen 2003: 330).

Dönok je prevzet iz nemškega dennoch (Kopečný idr. 1980: 165). V različnih izraznih variantah, npr. deno, denok, denk, je prisoten v vzhodnoslovenskem prostoru. Pojavi se kot okrepitev konektorjev, predvsem protivno-dopustnega veznika ali, $(4,5,17,33)$, redkeje tudi če glih 'čeprav', (8), in $i$ 'in', (32, 33). Ja se pojavi v zapisih premega govora kot povezovalno-modalni členek, s katerim se govorec odzove na predhodno repliko in izrazi zadržano strinjanje s prej povedanim, (24). Zagvüšno se pojavi v kombinaciji z ja kot povezovalno-modalni členek in okrepi zagotavljanje, (4). V osrednjeslovenski glasovni podobi zagvišno je naveden še pri Trubarju (Ahačič idr. 2011: 600).

(30) Boj dobre pameti kprotivniki tvojemi hitro, dokecs fzi na pouti znyi, naj te gda ne da protivnik fzodczi, i fzodecz te da hlapczi, i vtemniczo fze vr'zes. Zaifztino velim tebi: ne bos vo fou odnut, dokecs ne placsas te fzlednji fzoud. (Küzmič 1999: 15)

(31) Zaisztino nemore sze szpametno tajiti, ka vogrszki Orszak, v-sterom mi Szlovenye prebivamo, ma pravico od nasz terjati, naj sze pouleg nassega i nyegovoga Jezika navcsimo/./ (Košič 1833: X)

(32) Gledajte na fticze nebefzke: one ne fzejjajo, ni ne zenyayo, niti ne fzpravlajo vu skegnye, i dönok Ocsa vas nebefzki nye hrani. (Küzmič 1999: 20)

(33) A: Sterih düse ido v-Purgatorium? / B: Onih, ki fzo toti vu Bo'soj milocsi z-etoga fzvejta preminoli, ali fzo dönok vu fzvojem 'sitki za fzvoje vcsinyene grejhe Bo'soj pravicsi zadofzta nej vcsinili. (Küzmič 1851: 30)

\subsection{Izvzem}

\subsubsection{Nači (Vest.), ovak (C.)}

Prva skupina izvzemalnih členkov so poudarno-povezovalni, ki označujejo izvzem iz splošno sprejetega. Nači izvira iz praslovanskega pridevnika *in 'drug' (prim. Bezlaj 1976: 211). V vzhodnoslovenskem prostoru je poleg njega prisoten še inače, ki ga Pleteršnik označi kot slovenskogoriškega.

Ovak izvira iz praslovanske zaimenske osnove *ovb (Bajec 1954: 202, Bezlaj 1982: 262). Pojavi se tudi v kajkavščini. V vzhodnoslovenskem prostoru sta prisotni še varianti ovači in vači.

$\mathrm{V}$ besedilih se kot hapaks pojavi ovači (ovacsi: Kl 1), ki poudarja, da je stanje na splošno drugačno kot v trenutku govorjenja, in stoji znotraj stavka.

(34) Po logi je ovacsi dobra ceszta bila, ali zdaj je szneg szploh zaszipaol./ (Klekl 1904: 14) 
2.5.2 Listo (C.), listor (C., Mik.), leprav (C., Mik.), samič (C, Raič), li (C.)

Druga skupina so poudarno-povezovalni členki, ki izvzemajo del iz celote in izvzeti del obenem poudarjajo.

Listo(r) in leprav sta verjetno tvorjenki iz navezka le, ki naj bi po Miklošiču prišel iz obrušenega glej (Bajec 1954: 197). Listo se pojavi pri Krelju in Juričiču (Pleteršnik 1894/95, Ahačič idr. 2011: 213). Listo(r) in leprav sta prisotna tudi v kajkavščini. V prekmurskem knjižnem jeziku je listor zabeležen le za Severja in Bakoša, leprav in glasovna varianta lepraj pa sta pogostejša (prim. Novak 2006).

Samič je tvorjen iz praslovanskega ${ }^{*} s_{a m b}$ in pripone -ič (Bezlaj 1995: 215, prim. Bajec 1954: 18). Pleteršnik ga označi tudi kot vzhodnoštajerski. Ravno tako ga evidentira za časopis Zora.

$L i$ (KŠ 1) je rabljen enako kot izvzemalni le, (35). To je posledica mešanja členic le in $l i$ v narečjih (Bajec 1954: 197). Že iz Pleteršnikovega slovarja je možno razbrati, da gre za nadnarečen in nadzgodovinski pojav, ki zajame le in $l i$ kot členka v funkcijskem in besedotvornem smislu. Najpogostejši tovrstni členek v prekmurskem knjižnem jeziku je knjižni samo (fzamo: KŠ, 1; fzam: KM, 2; fzamo: KM, 1; szam: KM, 1; szamo: Koš, 4; K1, 5) (prim. Markoja 2004: 156).

Največkrat gre za poudarno-povezovalne členke, ki stojijo pred skopusom, (2, 35-38). V (39) pa se samo navezuje na cel stavek in meji na modalni členek, ki poudarja edino možno ravnanje in s tem izraža omilitev situacije.

(35) /M/olte za one, ki vafz fzküsavajo ino praganyajo. I.../ Ar, csi bodete lubili li te, ki vajs lubijo, kak fi najem bodete mell? Nej li publikanuske tou csinijo? (Küzmič 1999: 17)

(36) I, csi bodete fze poklanyali fzamo vafim bratom; ka obilnoga vcsinite? Nejli i publikanuske tak csinijo? Bojdite vi popolni, liki i Ocsa vas, fteri je vu nebefzaj, je popolni. (Küzmič 1999: 17)

(37) A: Jeli fzta tak dva Krifztuffa? / B: Nej fzta, nego je fzam eden Krifztus. (Küzmič 1851: 32)

(38) IS/zamo te szo mogli od zacsnyenoga dela henjati, geto je od Boga nyihov Jezik zmejsani/./ (Košič 1833: IX)

(39) $» / D / n e s z$ mo tesko pot meli.« "Naj sze szamo nebojijo, Krisztina» trostala jo ta sztarejsa. (Klek1 1904: 13)

\subsection{Vprašanja}

Jeli (C.)

Jeli 'ali, kajne' je v Pleteršnikovem slovarju označen kot vprašalni členek. Je splošnoslovanska beseda iz protetičnega $j$ - ter členic $e$ in li (prim. Bezlaj 1976: 
124, 1982: 138, Kopečný idr. 1980: 279). V prekmurskem knjižnem jeziku sta podani še varianti jelibar in jeltebar, narečno pa še deli in geli.

V besedilih se pojavi samo jeli 'ali' (KM 11; K1 4). V vseh primerih rabe velja stalna stava vprašalnega členka jeli, tj. »pravilo o naslonkah, ki lahko stojijo na začetku vprašalnih stavkov brez vprašalnice« (Pavel 2013: 375). Pri Kleklu se pojavi v dialogih, (24). Kot vprašalni členek je najpogostejši v Küzmičevem katekizmu, ki kot besedilna vrsta temelji na vprašanjih in odgovorih, (37). Če je del vezniške zveze jeli - ali (pa), meja med vprašalnim členkom in sestavnim delom vezniške zveze ni ostra. V (21) je sicer bliže vezniku, ker uvaja ponujena možna odgovora na dopolnjevalno vprašanje, v (40) pa uvaja odločevalno vprašanje in obenem ponujena možna odgovora nanj.

(40) A: Jeli je rodjeni Szin Boug od Boga Ocse, ali pa od nyega fzhaja? / B: Rodjeni je Szin Boug od Ocse. (Küzmič 1851: 29)

Za uvajanje odločevalnega vprašanja se pojavi še zveza zanikanega glagola biti in vprašalnega členka $l i,(35)$, ki je lahko tudi sklopljena v vprašalni členek nejli (13) (nej li: KŠ 1; nejli: KS̆ 2).

\section{Glavne ugotovitve}

Glede na stanje v Pleteršnikovem slovarju in ostalem gradivu je tipično prekmurski členek edino ěšce 'še'. Veliko danih členkov se pojavi v celotnem vzhodnoslovenskem prostoru (npr. dönok, pali, zaistino, ve(nda), nači, (o)vači, te, tak). Torej je tudi pri členkih vidna skupna panonska baza obeh vzhodnoslovenskih različic.

Pleteršnik s kvalifikatorjem ogr. večkrat označi členke, evidentirane v kajkavščini (npr. jošče, išče, vre, konči(mar) oz. končema, veče, ovak oz. ovači, nači, listor, leprav). Nekateri izmed njih (npr. listo(r), vre) iz glasoslovnih oz. besedotvornih razlogov sploh ne morejo biti hrvaški in so prisotni tudi v osrednjeslovenskem prostoru. Zato niso pravi kajkavizmi, ampak so jih prekmurski avtorji verjetno občutili kot kajkavske in se jim zato izogibali (prim. Jesenšek 1992: 177-178).

Germanizmi so le štirje (dönok, gli, ja, zagvëšno), kar je v primerjavi z osrednjeslovenskim jezikom malo. Obravnavani členki so bliže praslovanskim variantam kot osrednjeslovenski in knjižni (prim. Jesenšek 1992: 175, 2013: 51). Nekatere besede $\mathrm{v}$ osrednjeslovenskem in sodobnem slovenskem knjižnem jeziku ne obstajajo (npr. končimar, nači, ovak). Nekatere pa so le glasoslovne ali besedotvorne različice osrednjeslovenskih oz. knjižnih (npr. ešče, išče, jošce, veče, zavzpet, teda). Pri slednjih se raba od osrednjeslovenske ali knjižne ne razlikuje. 


\section{Sklep}

Prispevek obravnava prekmurske členke v Pleteršnikovem slovarju in ostalih relevantnih virih. Členki so umeščeni v širši vzhodnoslovenski prostor in postavljeni v razmerje s kajkavščino, osrednjeslovenskim in sodobnim slovenskim knjižnim jezikom. Predstavljen je tudi njihov etimološki izvor. Če strnemo glavne ugotovitve, je le ešč tipično prekmurski členek, ostali pa se pojavijo v celotnem vzhodnoslovenskem prostoru ali v kajkavščini. Mnogi so tudi glasovne oz. besedotvorne variante osrednjeslovenskih oz. knjižnih in so etimološko bliže praslovanskim variantam od njih.

Raziskava je zaradi težje dosegljivosti virov žal narejena na okrnjenem korpusu besedil. Za zanesljivejše in izčrpnejše ugotovitve bi bilo treba pregledati več ustreznega gradiva. Kljub temu pa prinaša sistematično predstavitev členkov za izražanje izbranih pomenskih odtenkov v prekmurskem in širšem vzhodnoslovenskem prostoru in je solidno izhodišče za nadaljnje delo.

VIRI IN LITERATURA

Viri

Kozma AHAČIČ idr., 2011: Besedje slovenskega knjižnega jezika 16. stoletja. Ljubljana: Založba ZRC, ZRC SAZU.

France BEZLAJ, 1976: Etimološki slovar slovenskega jezika I. Ljubljana: Mladinska knjiga.

- -, 1982: Etimološki slovar slovenskega jezika II. Ljubljana: Mladinska knjiga.

- -, 1995: Etimološki slovar slovenskega jezika III. Ljubljana: Mladinska knjiga.

- -, 2005: Etimološki slovar slovenskega jezika IV. Ljubljana: Mladinska knjiga.

Franjo HRG, 1996: Ivanečki govor i riječnik. Ivanec: Narodno sveučilište Đuro Arnold. Jurij JAPELJ, 1784: Svetu pismu noviga testamenta. Labaci: typis Joan. Frid. Eger.

Radoslav KATIČIĆ (ur.), 1984-86: Rječnik hrvatskoga kajkavskoga književnog jezika 1. Zagreb: Hrvatska akademija znanosti i umjetnosti, Institut za hrvatski jezik i jezikoslovje.

- -, 1988-91: Rječnik hrvatskoga kajkavskoga književnog jezika 2. Zagreb: Hrvatska akademija znanosti i umjetnosti, Institut za hrvatski jezik i jezikoslovje.

--, 1995-2002: Rječnik hrvatskoga kajkavskoga književnog jezika 3. Zagreb: Hrvatska akademija znanosti i umjetnosti, Institut za hrvatski jezik i jezikoslovje.

- -, 2005: Rječnik hrvatskoga kajkavskoga književnog jezika 4. Zagreb: Hrvatska akademija znanosti i umjetnosti, Institut za hrvatski jezik i jezikoslovje.

Jožef KOŠIČ, 1833: Predgovor. Kratki navuk vogrskoga jezika za začetnike. V Gradci: Papir ino natiskanje od Lejkam Andrasa. III-XVI. 
Mikloš KÜZMIČ, 1851: Pridavek. Kratki krsčanski navuk za malo deco. Slovenski silabikar. Gratzi: Pri Weitzinger J. A. [28-39].

Štefan KÜZMIČ, 1999: Szvetoga Mataja III. Tao Evangyelioma. Nouvi zakon ali Testamentom gospodna našega Jezusa Kristusa. Faksimile. Ljubljana: Svetopisemska družba Slovenije, Slovensko protestantsko društvo Primož Trubar. 10-21.

Franc NOVAK, Vilko NOVAK, 1985: Slovar beltinskega prekmurskega govora. Murska Sobota: Pomurska založba.

Vilko NOVAK, 2006: Slovar stare knjižne prekmurščine. Ljubljana: Založba ZRC, ZRC SAZU.

Avgust PAVEL, 2013: Prekmurska slovenska slovnica. Ur. Marko Jesenšek. Maribor: Mednarodna založba Oddelka za slovanske jezike in književnosti, Filozofska fakulteta. (Mednarodna knjižna zbirka Zora, 100).

Maks PLETERŠNIK, 1894/95: Slovensko-nemški slovar. <http://bos.zrc-sazu.si/pletersnik.html>.

- -, 2006: Slovensko-nemški slovar. Transliterirana izdaja. Prvi del A-O. Ur. Metka Furlan. Ljubljana: Založba ZRC, ZRC SAZU.

Bernard RAJH, 2010: Gučati po antujoško. Maribor: Mednarodna založba Oddelka za slovanske jezike in književnosti, Filozofska fakulteta. (Mednarodna knjižna zbirka Zora, 73).

[Szoboczanec], 1904: Bozsicsna zgodba. Ur. Jožef Klekl. Nevtepeno poprijeta devica Marija. Pobožen mesečen list 1/1. Črešnjevci: Založnik Jožef Klek1. 11-17.

Sveto pismo na internetu. <www.biblija.net>.

Tržne in poklicne prisege. Središče ob Dravi.< http://nl.ijs.si/e-zrc/prisege2/html/SRE-1.4.html>.

Ivan VEČENAJ, Mijo LONČARIĆ, 1997: Rječnik govora Gole. Zagreb: Institut za hrvatski jezik i jezikoslovje.

\section{Literatura}

Maruška AGREŽ, 2013: Raba členkov v verskih in posvetnih didaktičnih besedilih 2 . polovice 18. stoletja. Družbena funkcijskost jezika. Ur. Andreja Žele. Ljubljana: Znanstvena založba Filozofske fakultete. (Obdobja 32). 11-17.

- -, 2014a: Poudarni in modalni členki v slovenskih pridigah in pasijonski igri konca 17. in začetka 18. stoletja. Fiatal szlavisták Budapesti nemzetközi konferenciája II. Ur. Aleksander Urkom. Budapest: István Lukács. 5-10.

- -, 2014b: Te pa po štajersko - besedi pa in te v delih Petra Dajnka in v slovenskogoriškem narečju. Philoslovenica. Mednarodno znanstveno srečanje doktorskih študentov slovenistike in slavistike. Ur. Nina Ditmajer. Maribor: Zveza društev Slavistično društvo Slovenije, Slavistično društvo Maribor. 33-43.

,$-- 2014 c$ : Pet vrst členkov v slovenskih pogovorih in dramatiki med 17. in 19. stoletjem. [Prispevek za mednarodno znanstveno srečanje mladih Slavistov. Budimpešta, 2014. V postopku objave.] 
Hans ALTMANN, 1976: Die Gradpartikeln im Deutschen. Tübingen: Niemeyer.

Anton BAJEC, 1954: Prislovni paberki. Slavistična revija 5/7, 195-226.

Ivana ČERNELIČ, 1993: O delitvi členkov. Vprašanja slovarja in zdomske književnosti. Ur. Milena Hajnšek Holz. Ljubljana: Zavod Republike Slovenije za šolstvo in šport. 213-227.

Aleksandra IVANŠEK, 2009: Leksika tradicionalnih in prazničnih jedi, običajev in kmečkih opravil v Bakovcih. Diplomsko delo. Mentorici Vera Smole in Mojca Horvat. Ljubljana: Filozofska fakulteta.

Marko JESENŠEK, 1992: Jezikovni sistemi v slovenskem (alpskem in panonskem) govornem območju. Jezik in slovstvo 37/7, 173-181.

- -, 2007: Cafovo jezikoslovno delo in zbirka besed iz Frama. Besedje slovenskega jezika. Ur. Marko Jesenšek idr. Maribor: Slavistično društvo Maribor. (Zora 50). 177-199.

--, 2013: Poglavja iz zgodovine prekmurskega knjižnega jezika. Maribor: Mednarodna založba Oddelka za slovanske jezike in književnosti, Filozofska fakulteta. (Mednarodna knjižna zbirka Zora, 90).

Mihaela KOLETNIK, 1995: Severozahodni goričanski govori. Magistrsko delo. Mentorici Zinka Zorko in Martina Orožen. Ljubljana: Filozofska fakulteta.

- -, 2001: Slovenskogoriško narečje. Maribor: Slavistično društvo Maribor. (Zora 12).

František KOPEČNÝ idr., 1980: Etimologicky slovnik slovanskych jaziku. Praha: Academia.

Tomo KOROŠEC, 2009: Členki v Trubarjevem Katekizmu 1550. Slavistična revija (Trubarjeva številka), 222-230.

Darja MARKOJA, 2004: Oblikoslovna podoba besedil prekmurskega knjižnega jezika od 18. do 20. stoletja. Magistrsko delo. Mentorica Irena Orel. Ljubljana: Filozofska fakulteta.

Jožica NARAT, 1998: Oznaka ogr. v Pleteršnikovem slovensko-nemškem slovarju. Vatroslav Oblak. Ur. Alenka Šivic Dular. Ljubljana: Center za slovenščino kot drugi/ tuji jezik. (Obdobja 17). 167-181.

- -, 2005: Cafove prekmurske besede v Pleteršniku. Prekmurska narečna slovstvena ustvarjalnost. Ur. Jože Vugrinec. Murska Sobota: Solidarnost. 99-129.

Martina OROŽEN, 2003: Razvoj slovenske jezikoslovne misli. Maribor: Slavistično društvo Maribor. (Zora 26).

Bernard RAJH, 1998: Knjižnojezikovno delo Petra Dajnka kot poskus standardizacije vzhodnoslovenskega narečja. Doktorsko delo. Mentorici Zinka Zorko in Martina Orožen. Ljubljana: Filozofska fakulteta.

Suzana RAJNAR, 1998: Prekmurski govori na Goričkem. Magistrsko delo. Mentorica Zinka Zorko. Ljubljana: Filozofska fakulteta.

Jakob ŠOLAR, 1958: Vloga in mesto členka tudi. Jezik in slovstvo 3/4, 158-161.

--, 1959: Veznik in. Jezik in slovstvo 5/2, 14-18. 
Natalija ULČNIK, 2009: Začetki prekmurskega časopisja. Besedje Agustičevega časopisa Prijatel. Maribor: Filozofska fakulteta, Mednarodna založba Oddelka za slovanske jezike in književnosti. (Mednarodna knjižna zbirka Zora, 67).

Drago UNUK, 1995: Zahodni prleški govori. Magistrsko delo. Mentorici Zinka Zorko in Martina Orožen. Ljubljana: Filozofska fakulteta.

\section{PREKMURIAN PARTICLES IN PLETERŠNIK'S DICTIONARY}

This paper discusses particles (i.e. functional words, modifying the meaning of a part of a text by expressing time, deduction, addition with emphasizing, minimality, exception, agreement and questions) in the Prekmurian language, which includes the Prekmurian Standard Language and dialects. The basis for the analysis is Pleteršnik's Slovene-German dictionary (1894/95), the first relevant source of Prekmurian words, which are labeled with ogr. there. The analysis also includes other dictionaries and relevant inventories of Eastern Slovene (i. e. the Prekmurian and Eastern Styrian Standard Languages and dialects) and Kajkavian words. The use of particles is analysed in texts, written in the Prekmurian Standard Language between the $18^{\text {th }}$ and $20^{\text {th }}$ centuries: Stefan Küzmič's translation of The New Testament (1771), Košič's Hungarian grammar for beginners (1833), the reprint of Mikloš Küzmič's Catechism (1851) and Klekl's periodical Nevtepeno poprijeta devica Marija (1904). The only typically Prekmurian particle is $e \check{s} \check{c} e$, an etymologically older variant of Central (i. e. the Central Slovene Standard Language and dialects) and contemporary Standard Slovene $\check{s}$. Otherwise many of these particles exist either throughout all of Eastern Slovene (e.g. dönok, pali, zaistino) or in the Kajkavian Standard Language or dialects (e. g. išče, jošče, konči(mar), listor, tolikajše, vre). The latter rarely appear in the texts as Prekmurian authors might have felt them to be Kajkavian and therefore avoided using them. However, these words are not necessarily typical Kajkavian. Some of them exist even in Central Slovene. The inventory of the particles, discussed in the paper, contains three loanwords from German (dönok, ja, zagvüšno), which is few in comparison to Central Slovene. Some Eastern Slovene particles in general do not exist in Central and Standard Slovene (e. g. dönok, nači, ovak). Many of them differ from Central and Standard Slovene ones in word formation and/or phonology and are more similar to their Proto-Slavic variants (e.g. ěšce, $i$, pali, tüdi, veče), but their use is the same as in Central and Standard Slovene. 